\title{
Opaque Ventilated Façade (OVF) Thermal Performance Simulation for Office Buildings in Brazil
}

\author{
Camila Gregório-Atem ${ }^{1}\left[\begin{array}{l}\text {, } \\ \text {, Carolina Aparicio-Fernández }\end{array}\right.$ \\ José-Luis Vivancos ${ }^{4}$ [D \\ 1 Civil, Construction Engineering Department, State University of Londrina, Londrina 86057-970, Brazil; \\ camila.atem@uel.br \\ 2 Department of Architectural Constructions, Universitat Politècnica de València, Camino de Vera s/n, \\ 46022 Valencia, Spain \\ 3 Architecture, Energy \& Environment, School of Architecture of Barcelona, UPC, Av. Diagonal, 649, 7th Floor, \\ 08028 Barcelona, Spain; helena.coch@upc.edu \\ 4 GIDDP, Departamento de Proyectos de Ingeniería, Universitat Politècnica de València, Camino de Vera s/n, \\ 46022 Valencia, Spain; jvivanco@dpi.upv.es \\ * Correspondence: caap@csa.upv.es; Tel.: +34-96-387-7000 (ext. 74586)
}

Received: 14 July 2020; Accepted: 8 September 2020; Published: 16 September 2020

\begin{abstract}
Opaque ventilated façades (OVFs) are increasingly gaining in importance in the design of sustainable buildings, given that they can lessen the building's environmental impact. Opaque ventilated façades can reduce thermal gains in hot climate zones, improving the thermal comfort indoors, and reducing air conditioning demand. Nevertheless, the thermal behaviour of the opaque ventilated façade depends on the climatic conditions and the building's specific design. This study analyses the effect of opaque ventilated façades in office buildings using 30 constructive configurations under eight tropical climate conditions. The study considers three options for the external layer of cladding (ceramic, stone, and aluminium composite material) and two configurations for the inner layer (plasterboard with mineral wool and ceramic). Simulations were carried out using the software tools TRanNsient SYstem Simulation program (TRNSYS) and TRNFlow. The model developed considers bioclimatic characteristics, including solar radiation and wind conditions for each climatic zone. The operating temperature was selected from within the range established by occupant comfort regulations. The findings suggest that it is possible to select the best office building opaque ventilated façade configuration for each of the specific climate conditions in Brazil.
\end{abstract}

Keywords: ventilated façade; building simulation; tropical climates; energy demand

\section{Introduction}

The building's envelope characteristics, particularly its suitability, have great influence on the building's annual heating and cooling consumption, which influences dependence on the grid energy supply [1,2], especially in detached and high-rise buildings, which are common in tropical climate zones, where the atmosphere is usually hot and humid. According to European research [3-6], the opaque ventilated façade's $(\mathrm{OVF})$ potential to reduce heating gains is quite large in the summer, ranging from $20 \%$ to $40 \%$. This type of envelope was introduced in the early 2000s in many countries from the Southern Hemisphere based on proven efficiency in Northern Hemisphere countries. The lack of performance data in real buildings became a barrier in countries within the Southern Hemisphere. In fact, there are very few studies that analyse the OVF's thermal behaviour in tropical and subtropical climates $[7,8]$, notwithstanding its demonstrated thermal performance in other countries. OVF systematic design approaches in tropical and subtropical climates are missing out on the state of the art developments 
and therefore, a complete study is necessary, which includes a range of climatic zones and layer compositions, to verify if, in this heterogeneous country, it is worth investing in OVF to obtain a more efficient building, given the lack of data on the OVF's thermal behaviour to support design decisions.

Approximately $81.4 \%$ of Brazilian territory is under tropical climate conditions. In Brazil, over the last few decades, concern has grown over the energy demand of buildings, as the country is experiencing a sharp annual increase in electricity demand. In 2018, the electricity generated by the Brazilian public services and self-generator power plants reached $601.4 \mathrm{TWh}, 2.0 \%$ higher than the previous year [9]. Brazilian buildings consume $50 \%$ of the total electricity demand, and of these, $16.9 \%$ are commercial, $25.4 \%$ residential, and $8.2 \%$ public buildings. Building energy consumption from the commercial sector has grown by $25.6 \%$ in the last 10 years, reaching $99.01 \mathrm{TWh}$. Public and commercial buildings' demand for air conditioning is $28 \%$ [10]. Therefore, it is increasingly important to investigate new passive strategies such as OVF and verify their benefits to determine their capability to reduce the energy demand of buildings.

OVF is an industrial multilayer façade composed of two opaque sheets and a middle-ventilated air gap, which promotes the lowest thermal gains in hotter weather conditions [11,12]. Given its versatility, it is possible to select its colour, outer skin material, thermal insulation thickness, air gap width, and inner skin material.

When OVF first reached Brazil, where the climate is quite different from Europe, it was assumed to be a high energy efficient building solution. Nevertheless, Brazil's energy demand is driven by the need for cooling, which is different from European building energy demand. However, there has been little research $[7,13]$ to demonstrate whether under specific Brazilian climatic conditions this façade's typology would bring any benefit. Previous research on this issue has been limited to only one city and for just one season. No annual study was found, nor a complete simulation work that analyses each country's climatic zones.

This work accumulates a large amount of data regarding OVF's performance in a sample office building over a year, simulating its location in eight different Brazilian zones influenced by a range of climate conditions. Data provided by this study will therefore help the early stage decision making for the sustainable design of OVF buildings depending on their location and the climatic conditions.

\section{Opaque Ventilated Façades (OVFs) with Natural Ventilation}

According to some authors, an OVF's main benefit is its capability to reduce thermal gains in hot climates, thus seeking to improve thermal comfort inside buildings and reducing air conditioning consumption $[3-6,13,14]$. OVF's thermal behaviour depends on climatic conditions such as solar radiation, wind direction and speed, air temperature, and the building's specific design (geometries and materials). The complexity of understanding a building's thermal behaviour has led to many investigations which have been mainly focused on the performance of the air chamber, considering parameters such as air speed, turbulence, air direction or air temperature. The building's thermal behaviour according to wind speed and direction, solar radiation and orientation, night thermal behaviour, characteristics, and the influence of forced ventilation have been analysed, although only a few studies have demonstrated their influence by simulating a range of envelope compositions, materials, and colours.

Research from Mediterranean countries has demonstrated that, in hot climate zones, when the outer skin and the air gap are radiated, natural convection is affected by the façade's materials, and an optimal solution can reduce the cooling demand $[4,5,12,13,15]$.

Understanding the heat exchange process in multi-layer façades is not a simple task, given the many variables that must be considered. Nevertheless, most papers analyse only one specific parameter without evaluating the parametric interaction between them. Thus, it is worth noting that exhaustive research has been done looking at building orientation and solar radiation $[4,13,15-17]$, in which it is shown how energy savings increase when solar radiation rises [11,13-15]. The ventilation of the air gap has also been previously simulated, including a model development and validation that 
successfully predicts the air gap's behaviour [5]. Analysis of the ventilation of the air chamber has demonstrated the potential energy savings achieved when the air velocity inside the gap increases. In addition, the chamber's air velocity is directly influenced by the amount of radiation affecting the façade: the more radiation, the higher the air velocity $[11,18,19]$. In this work, evidence has been found concerning the relationship between the increased gap's ventilation and solar radiation incidence, concluding that if the outer leaf temperature increases because of solar radiation, the air movement inside the chamber also increases. Therefore, if solar radiation does not affect the outer layer, the outdoor temperature is equal to that of the air gap, and no air movement is driven by temperature difference. Fantucci et al. [20] demonstrated the effectiveness of OVFs in preventing solar gains in façades, with an estimated reduction ranging between $52 \%$ and $64 \%$.

Some investigations focused on the air movement influenced by the air cavity's characteristics [12-15]. However, only a few of them analysed different OVF materials, one of which deals with the different layers that define the enclosure [21]. This work modifies the façade's mass position through experimental research and concludes that, for the specific climate conditions in Italy, the adoption of a thermal mass in contact with the air gap, no matter its position, can reduce heat transfer. Also, many significant researchers have noted the inertia importance in climates with high thermal amplitudes, highlighting that the mass should preferably be positioned on the outside of the cavity, to guarantee lower incoming/outgoing fluxes and a higher stack effect. Another investigation carried out by Prada [22] compared two case studies, one of which considers insulation behind the air chamber, and the other considers no insulation. They noted that the insulated wall reached higher air velocity along the wall's height, provided by the higher temperatures reached inside the air gap.

Ciampi [13] analysed the outer and inner layers, studying the effect of different materials and external layer thickness, and concluded that when the outer skin is made of reflecting materials, the influence of solar radiation on the façade is strongly reduced, as is the ventilated gap's efficiency. Another fact to consider is that energy savings increase when the outdoor and indoor temperature difference decreases. Further work which has analysed the external layer conditions [4] concluded that the outer layer's materials with lower absorption coefficients produce higher energy savings, suggesting the use of materials with low thermal conductivity, high density, and high specific heat, and highlighting that metals generate overheating at midday.

OVF's external enclosures were qualitatively compared by Stazi [11], who showed that the external cladding inertia influences the chimney effect over time in ceramic façades, which is more effective for cladding with low inertia at night, unlike during the day, when those with higher thermal inertia are most effective.

The façade's outer layer characteristics has been one of the least analysed elements until 2014 [12], when Marinosci studied the ventilated façade's behaviour in relation to the outer material, the openings, and the air chamber's thickness, concluding that outer stone cladding works better than aluminium plates because of its greater thermal inertia and resistance.

Another element to be analysed is thermal insulation's role in OVFs [13]. The most common thermal insulation arrangement is within the air gap, near the inner masonry wall, although previous research suggested that it may not be the most energy-efficient solution, suggesting that the optimal insulation position is between the inner masonry wall and the outer layer.

Previous research looking at the temperature patterns inside the air chamber [23] has suggested that the high temperatures reached in summer can lead to poor façade behaviour, requiring greater inner sheet insulation. The authors stated that further in-depth research was needed to improve the system design. The literature reviewed highlighted the lack of evidence on the effect of the OVF's inner sheet characteristics and its thermal inertia [3].

The thermal behaviour of a ventilated granite façade is compared with a traditional granite solution in Brazil, where a great variety of tropical and subtropical climates can be found [7]. So far, this envelope's typology is most energy efficient in warmer climates with high solar radiation, high temperatures, and very low wind speed, as the air flowing through the ventilated chamber 
reduces the solar gains inside the building. For the coldest periods and locations, ventilated façades achieved poorer performance than traditional façades. Hence, for a country like Brazil, with such varied climate conditions, greater OVF parametric studies are needed to show its effect on the building's energy demand. The work presented here feeds into this parametric work, focusing on office buildings, which require high energy demand [24]. Thus, the aim of this work is to take a further step towards the efficient design of the ventilated façade in tropical climates using a previously validated TRanNsient SYstem Simulation program (TRNSYS) model. A calculation tool called TRNFlow has also been used to simulate the ventilated air gap's behaviour. This software estimates solar gains (solar radiation) on each façade.

\section{Methodology}

A model previously developed and validated for a given office building has been applied here [23]. Tropical climate conditions were selected from current values given in Brazilian regulations [25]. Eight cities located within Brazilian tropical locations according to the Köppen-Geiger classification and Brazilian regulations have been selected. Additionally, 30 building designs were modelled (five materials for the inner wall, and three materials and two colours for the external layer), which resulted in a total of 240 simulations performed with TRNSYS 17 and TRNFlow. The inner wall characteristics were those from the validated model, adding three new proposals that are common in Brazil. The external layer's materials from the validated model were compared with two common materials used in Brazilian office buildings [26].

\subsection{Climatic Conditions Analysed}

The tropical climate location is bordered by the Tropics, and Brazil's latitude ranges from $5^{\circ} 16^{\prime} 19$ to the north to $33^{\circ} 45^{\prime} 09^{\prime \prime}$ to the south, so several tropical climatic conditions are present, including different temperatures, humidity, and solar radiation. Climatic areas in Brazil were established in 2005 by the Brazilian Association of Technical Standards [27], and these areas were used in this paper. The country has eight different zones according to each region's climatic conditions, although in this work, five climate locations have been sampled, evaluating eight Brazilian cities within those regions, as shown in Table 1 [28].

Zone 1 is the coldest area analysed, and Curitiba-PR represents $\mathrm{Cfb}$ climate (humid subtropical zone, oceanic climate with dry season and warm temperate summer). Zone 8, which is Am (tropical zone, monsoon), is the warmest and most humid, where Belém-PA is located.

Table 1. Cities and climates analysed in this study. (Am-tropical zone, monsoon; Aw-tropical zone, with dry winter; BSh—dry zone, steppe climate, low latitude and altitude; Cfa-humid subtropical zone, oceanic climate with dry season, with hot summer; $\mathrm{Cfb}$-humid subtropical zone, oceanic climate with dry season, with warm temperate summer) [28].

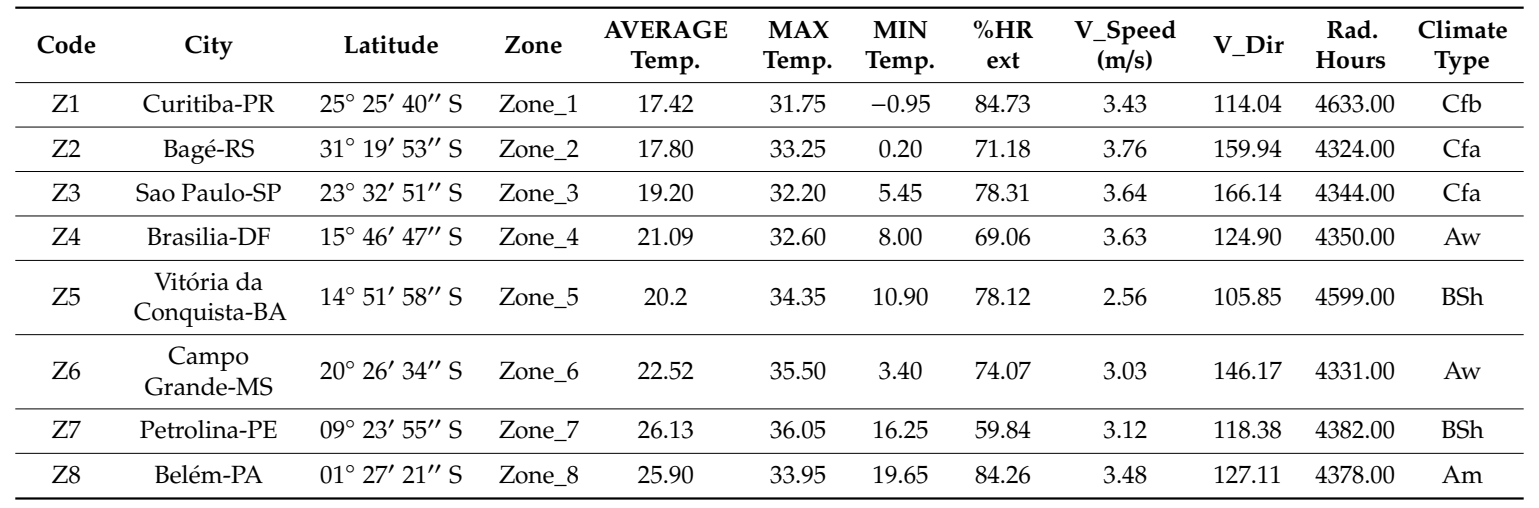




\subsection{The Building Model (Case Study/Building Simulation)}

The office building analysed here was previously simulated and validated by the authors [23]. The building is rectangular, as shown in Figure 1, being $92 \mathrm{~m}$ long, $17.5 \mathrm{~m}$ wide, and 3-4 floors high. The ground floor is conventional, whereas the others have a floating external sheet, which acts as a rainscreen. The building is east orientated, and windows are continuous in all façades. The constructive elements are defined in Table 3.

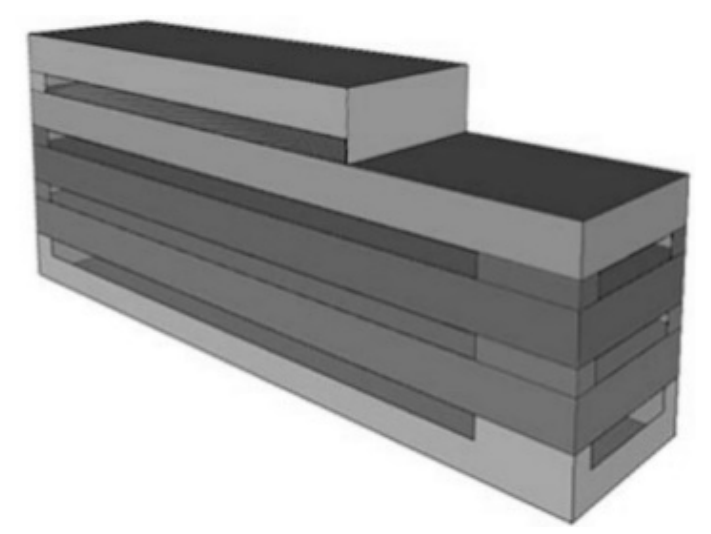

Figure 1. Building's simulated volume and shape.

An opaque ventilated system operates from the first floor to the top floor; the total façade area is $1428.20 \mathrm{~m}^{2}$ (excluding windows), the roof's U-value is $0.415 \mathrm{~W} / \mathrm{m}^{2} \mathrm{~K}$, and the floor's U-value is $0.39 \mathrm{~W} / \mathrm{m}^{2} \mathrm{~K}$, whose area is $1610 \mathrm{~m}^{2}$ per floor. Windows are double glazed 4/8/4, with a U-value of $3.25 \mathrm{~W} / \mathrm{m}^{2} \mathrm{~K}$ and a total area of $603 \mathrm{~m}^{2}$.

In the model, TRNSYS considers external weather data from the Meteonorm database included in TRNSYS [29] into TMY2 format for simulations (standard minute format with global horizontal solar radiation, dry bulb temperature, relative humidity, and wind speed and direction). The data file from Meteonorm contains average climatic readings over the period 1991-2010. TRNSYS calculates solar radiation on each surface of the building according to the weather data component (Type 99) and considers the building's components (Type 56). The software works by calculating solar gains, conduction, radiation and convection processes on the envelope of the building. TRNFLOW has been used to simulate the ventilated air gap's thermal behaviour. Therefore, solar gains (solar radiation) have been considered in the air gap, as have air flow conduction and convection through the gap.

Some information is essential in order to understand the data used in the simulations. The wind speed adjacent to the surface was calculated by TRNFLOW using weather data and wind pressure coefficients $(\mathrm{Cp})$ which depend on the shape of the building, wind direction and the analysed point on each surface of the façade [30]. The external surface resistance is defined by two coefficients: the radiative coefficient, which is a constant value $(\mathrm{hr}=5.13 \mathrm{~W} / \mathrm{m} 2 \mathrm{~K})$, and the convective coefficient, which is a function of wind speed $\mathrm{v}(\mathrm{hc}=4+4 \mathrm{v})$, according to EN ISO 6946: 2017 [31]. The outdoor temperature is given by each city's climatic data. The internal surface resistance is considered constant, using the tabulated value from the previous regulation ( $\mathrm{Rsi}=0.13 \mathrm{~m} 2 \mathrm{~K} / \mathrm{W})$. The air gap, which is considered to be slightly ventilated as demonstrated by previous work [23], has also been assumed from the current regulation [31].

Figure 2a shows the TRNSYS model developed. The input parameters are weather data and building occupancy, and the outputs are energy demand and room temperatures. Figure $2 \mathrm{~b}$ illustrates the TRNFLOW model with the inlet and outlet air and the connexions in the air chamber. The outdoor air is input on the first floor and output on the third floor. 


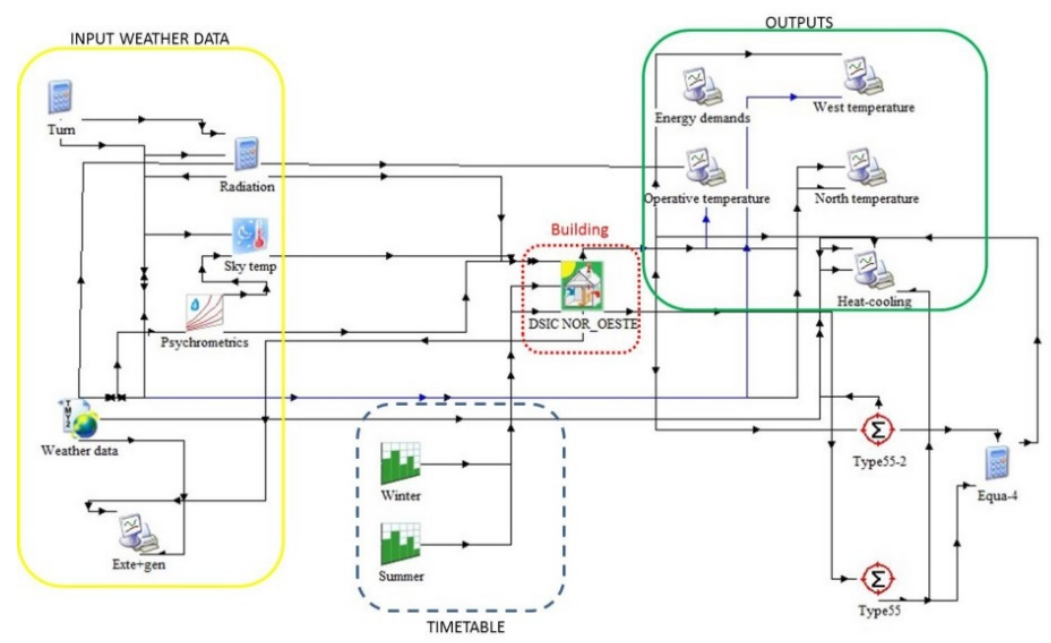

(a)

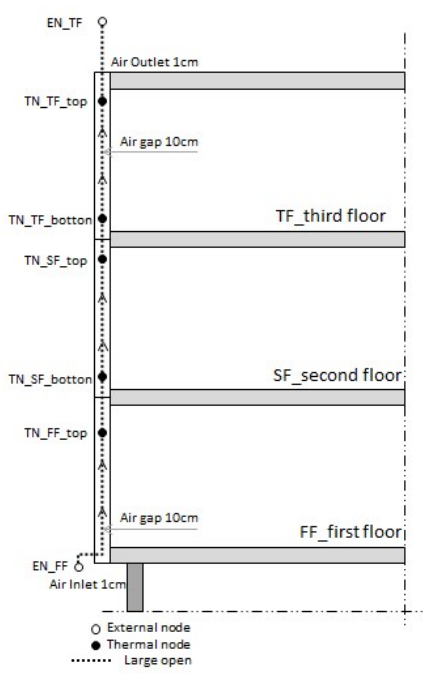

(b)

Figure 2. (a) TRNSYS model and the (b) TRNFlow model.

The office building occupancy, equipment, and lighting characteristics were also introduced to determine the internal thermal gain. Full office occupancy is assumed between 08:00 to 12:00 and between 14:00 and 18:00, considering 50 people working seated in the office supplied with lighting and office equipment. From 12:00 to 14:00, only 20\% occupancy is considered. The infiltration was assumed at 1 renovation per hour. These details are summarized in Table 2.

The building's energy performance accounts for both the heating and cooling demand. Surface temperatures were calculated for each façade configuration illustrating thermal envelope performance.

Table 2. Building thermal properties, occupancy, lighting, and equipment.

\begin{tabular}{|c|c|c|c|}
\hline \multicolumn{4}{|c|}{ Internal Gains } \\
\hline & $\begin{array}{l}\text { People } \\
\left(\mathrm{W} / \mathrm{m}^{2}\right)\end{array}$ & $\begin{array}{l}\text { Equipment } \\
\left(\mathrm{W} / \mathrm{m}^{2}\right)\end{array}$ & $\begin{array}{l}\text { Lighting } \\
\left(\mathrm{W} / \mathrm{m}^{2}\right)\end{array}$ \\
\hline Occupancy * 08:00-12:00/14:00-18:00 (100\%) & 18.65 & 17.41 & 17 \\
\hline Occupancy 12:00-14:00 (20\%) & 3.73 & 3.48 & 3.4 \\
\hline Non-occupancy 18:00-08:00 (0\%) & 0 & 0 & 0 \\
\hline Infiltration & \multicolumn{3}{|c|}{ One renovation per hour } \\
\hline Lighting & \multirow{2}{*}{\multicolumn{3}{|c|}{$\begin{array}{l}\text { Total heat gains } 17 \mathrm{~W} / \mathrm{m}^{2} \text { - convective part } 50 \% \\
\qquad 50 \text { computers- } 140 \mathrm{~W}\end{array}$}} \\
\hline Equipment gains and appliances & & & \\
\hline
\end{tabular}

\subsection{Thermal Comfort in Brazilian Office Buildings}

According to current regulations [27], it should be noted that heating demand is only needed in the south of the country (for this analysis, Z1, Z2, and Z3). In these climatic zones, winters are cold and space heating is required. Domestic space heating is normally supplied with a chimney or wood-burning stove, whereas in public buildings the use of heat pumps is common, and the cooling demand is covered with air conditioning.

Brazilian regulations consider comfort temperatures between $21^{\circ} \mathrm{C}$ and $27^{\circ} \mathrm{C}$ in hot climate zones [32]. In the simulation, the heating automatically turns on when the indoor temperature is below $21^{\circ} \mathrm{C}$, while the cooling turns on when the temperature is above $27^{\circ} \mathrm{C}$. 


\subsection{Parameters Considered}

The envelope's external layer in the validated model was dark in colour, made of aluminium composite (ACM), and $5 \mathrm{~mm}$ thick. It has a $10 \mathrm{~cm}$ air gap opened $1 \mathrm{~cm}$ at the top and the bottom, and $1 \mathrm{~cm}$ open joints between the OVF panels. The inlet and outlet air are always flowing, as it is not possible to close the gaps. The internal wall's insulation is made of plasterboard panels.

For the simulation, the air gap was considered constant while the different layers' characteristics were modelled. Table 3 lists all the façade materials considered. The materials' thickness and characteristics have been modelled according to existing commercial solutions.

Table 3. OVF Thermophysical properties based on previous research [33].

\begin{tabular}{cccccc}
\hline Item & Description & Thickness & $\begin{array}{c}\text { Density } \\
{\left[\mathbf{k g} / \mathbf{m}^{3}\right]}\end{array}$ & $\begin{array}{c}\text { Thermal } \\
\text { Conductivity } \\
{[\mathbf{W} / \mathbf{m K}]}\end{array}$ & $\begin{array}{c}\text { Specific } \\
\text { Heat } \\
(\mathbf{J} / \mathbf{k g ~ K})\end{array}$ \\
\hline 1 & Natural gypsum plasterboard & 0.016 & 900 & 0.25 & 1000 \\
2 & Mineral wool & 0.08 & 50 & 0.036 & 1000 \\
3 & Mortar Panel & 0.01 & 1200 & 0.23 & 1500 \\
4 & Rigid polyurethane foam (PUR/PIR) & 0.04 & 12 & 0.031 & 1500 \\
5 & Hollow ceramic & 0.10 & 1200 & 0.49 & 900 \\
6 & Solid ceramic & 0.10 & 1800 & 0.87 & 1400 \\
7 & Lime cement plaster & 0.025 & 1600 & 1.4 & 1100 \\
8 & Rigid polyurethane foam (PUR/PIR) & 0.05 & 12 & 0.031 & 1500 \\
9 & Stone tile (STO) & 0.03 & 2600 & 2.8 & 1000 \\
10 & Ceramic tile (CER) & 0.015 & 1600 & 0.76 & 1000 \\
11 & Aluminium composite material (ACM) & 0.004 & 980 & 5.65 & 1500 \\
\hline
\end{tabular}

Five different inner layer materials were combined with three external layer elements. The materials considered for analysis are the most common materials currently used in Brazil. It should be noted that Item B, from Table 4, with "hollow ceramic brick" is the most commonly used in recent years.

Table 4. Inner skin configuration.

\begin{tabular}{ccccc}
\hline Item & $\begin{array}{c}\text { Materials from Table } 2 \\
\text { from the Wall's Inner } \\
\text { Layer to the Outer Layer }\end{array}$ & Thickness [m] & U-Value [W/m $\mathbf{m}^{\mathbf{~ K}]}$ & $\begin{array}{c}\text { Energy } \\
\mathbf{M J} / \mathbf{m}^{\mathbf{2}}\end{array}$ \\
\hline $\mathrm{A}$ & $1+2+3+4$ & 0.146 & 0.245 & 357.50 \\
$\mathrm{~B}$ & $7+5+7$ & 0.153 & 2.285 & 211.75 \\
$\mathrm{C}$ & $7+6+7$ & 0.15 & 2.92 & 298.43 \\
$\mathrm{D}$ & $7+5+8$ & 0.178 & 0.603 & 345.83 \\
$\mathrm{E}$ & $7+6+8$ & 0.175 & 0.64 & 432.51 \\
\hline
\end{tabular}

The combination of materials tested for the outer and the inner skin resulted in 30 different OVF solutions as summarised in Table 5. There are two different solar absorptances for the external layer: light colour, with 0.2 solar absorptance, and dark colour with 0.6 solar absorptance. In all surfaces, the case emissivity was considered to be 0.9. In addition, for the external skin, three different materials, which are listed in Table 3, were considered: $0.03 \mathrm{~m}$ of stone (STO), $0.015 \mathrm{~m}$ of compact ceramic tiles (CER), and $0.004 \mathrm{~m}$ of aluminium composite material (ACM); the configurations for the inner skin are specified in Table 4. 
Table 5. Façade configuration for simulations.

\begin{tabular}{|c|c|c|c|c|c|c|c|c|c|}
\hline \multirow{2}{*}{$\begin{array}{l}\text { Skin } \\
\text { Type }\end{array}$} & \multicolumn{4}{|c|}{ Description } & \multirow{2}{*}{$\begin{array}{l}\text { Skin } \\
\text { Type }\end{array}$} & \multicolumn{4}{|c|}{ Description } \\
\hline & $\begin{array}{l}\text { Inner } \\
\text { Skin }\end{array}$ & $\begin{array}{l}\text { Thermal } \\
\text { Insolation }\end{array}$ & $\begin{array}{c}\text { Outer } \\
\text { Skin }\end{array}$ & $\begin{array}{l}\text { External } \\
\text { Colour }\end{array}$ & & $\begin{array}{l}\text { Inner } \\
\text { Skin }\end{array}$ & $\begin{array}{l}\text { Thermal } \\
\text { Insolation }\end{array}$ & $\begin{array}{l}\text { Outer } \\
\text { Skin }\end{array}$ & $\begin{array}{l}\text { External } \\
\text { Colour }\end{array}$ \\
\hline ACM_A1 & $\mathrm{A}$ & Yes & $\mathrm{ACM}$ & 0.6 & ACM_C2 & C & No & $\mathrm{ACM}$ & 0.2 \\
\hline CER_A1 & A & Yes & CER & 0.6 & CER_C2 & $\mathrm{C}$ & No & CER & 0.2 \\
\hline STO_A1 & A & Yes & STO & 0.6 & STO_C2 & $\mathrm{C}$ & No & STO & 0.2 \\
\hline ACM_A2 & $\mathrm{A}$ & Yes & $\mathrm{ACM}$ & 0.2 & ACM_D1 & $\mathrm{D}$ & Yes & $\mathrm{ACM}$ & 0.6 \\
\hline CER_A2 & $\mathrm{A}$ & Yes & CER & 0.2 & CER_D1 & $\mathrm{D}$ & Yes & CER & 0.6 \\
\hline STO_A2 & A & Yes & STO & 0.2 & STO_D1 & $\mathrm{D}$ & Yes & STO & 0.6 \\
\hline ACM_B1 & B & No & $\mathrm{ACM}$ & 0.6 & ACM_D2 & $\mathrm{D}$ & Yes & $\mathrm{ACM}$ & 0.2 \\
\hline CER_B1 & B & No & CER & 0.6 & CER_D2 & D & Yes & CER & 0.2 \\
\hline STO_B1 & B & No & STO & 0.6 & STO_D2 & $\mathrm{D}$ & Yes & STO & 0.2 \\
\hline ACM_B2 & B & No & $\mathrm{ACM}$ & 0.2 & ACM_E1 & $\mathrm{E}$ & Yes & $\mathrm{ACM}$ & 0.6 \\
\hline CER_B2 & B & No & CER & 0.2 & CER_E1 & $\mathrm{E}$ & Yes & CER & 0.6 \\
\hline STO_B2 & B & No & STO & 0.2 & STO_E1 & $\mathrm{E}$ & Yes & STO & 0.6 \\
\hline ACM_C1 & $\mathrm{C}$ & No & $\mathrm{ACM}$ & 0.6 & ACM_E2 & $\mathrm{E}$ & Yes & $\mathrm{ACM}$ & 0.2 \\
\hline CER_C1 & C & No & CER & 0.6 & CER_E2 & $\mathrm{E}$ & Yes & CER & 0.2 \\
\hline STO_C1 & $\mathrm{C}$ & No & STO & 0.6 & STO_E2 & $\mathrm{E}$ & Yes & STO & 0.2 \\
\hline
\end{tabular}

\section{Results and Discussion}

For each case study, the heating, cooling and annual energy demands have been calculated, resulting in 240 simulations, which provide a great source of analysis. With the simulation program set as a transient system, it has been possible to hourly simulate the thermal behaviour of each constructive solution during a calendar year. Annual energy consumption results are displayed in Table 6 (the annual heating and cooling demands are attached on Appendix A, Table A1.)

Given that Zone 1 is the coldest zone, the solution with the lowest thermal transmittance (U-value) results in the lowest annual heating demand; therefore, a dark ceramic external layer with insulated plasterboard (CER_A1) in the internal layer is the best solution. The very similar results were found with the outer skin made of dark coloured aluminium composite and insulated plasterboard in the camera (ACM_A1) both for Zone 1 and Zone 2 (the coldest areas with the highest insulated constructive proposals). The heating and cooling analyses from Zones 1, 2, and 3 show that the highest heating demand is obtained with the external layer made of light colour stone and the inner layers made of hollow ceramic brick with lime cement plaster and no insulation (STO_C2), which results, in turn, in the lowest cooling demand. Similarly, the lowest heating demand is reached with ACM_A1, which is the least efficient solution for cooling. Thus, among the inner layers analysed, the lightest and most isolated one is item $\mathrm{A}$, which resulted in the minimum annual demands within Zone 1 and Zone 2. The stone tile STO_C2, which has less thermal resistance, results in most cases in the lowest cooling demand, as found by previous research $[4,12,13,21]$. Previous studies have indeed calculated the summer cooling demand but lack the annual energy demand analysis, which is highly relevant in this work, concluding that higher thermal transmittance values decrease summer cooling loads but increase the winter heating demand, being the least efficient solution for cold climates. Results within Zone 1 and Zone 2 are quite similar because of their comparable weather conditions, where the insulated inner layer is the best option.

Within Zone 2 (Bage-RS), the highest annual and heating demand is achieved with STO_C2. The lowest heating demand is obtained with ACM_A1 (91.64 $\mathrm{kWh} / \mathrm{m}^{2}$ year), and the lowest annual demand is achieved with CER_A1 $\left(112.20 \mathrm{kWh} / \mathrm{m}^{2}\right.$ year). It should be noted that the results from applying the dark colour aluminium composite on the outer skin, hollow ceramic brick with lime cement plaster inside and no insulation (ACM_C1), and CER_A1 are quite similar, $112.20 \mathrm{kWh} / \mathrm{m}^{2}$ year and $112.30 \mathrm{kWh} / \mathrm{m}^{2}$ year respectively, both with insulation. Similar performance is found in Zone 1 . Total energy demand in Zone 3 is lower than that in Zones 1 and 2, although the cooling demand increases. The best option for this case study is (CER_E2) with insulation and solid ceramic brick inside, although the result is very close to CER_A1's in Zones 1 and 2. 
Table 6. Simulation results. Total energy demand in $\mathrm{kWh} / \mathrm{m}^{2}$ year.

\begin{tabular}{|c|c|c|c|c|c|c|c|c|}
\hline & Zone 1 & Zone 2 & Zone 3 & Zone 4 & Zone 5 & Zone 6 & Zone 7 & Zone 8 \\
\hline CASES & Total & Total & Total & Total & Total & Total & Total & Total \\
\hline ACM_A1 & 81.58 & 112.30 & 57.51 & 35.42 & 42.00 & 74.08 & 136.51 & 119.93 \\
\hline CER_A1 & 81.54 & 112.20 & 57.35 & 34.90 & 41.38 & 73.33 & 135.46 & 118.86 \\
\hline STO_A1 & 92.26 & 124.91 & 64.39 & 36.48 & 41.98 & 75.80 & 139.26 & 121.93 \\
\hline ACM_A2 & 82.73 & 112.88 & 57.97 & 34.65 & 39.96 & 72.41 & 133.30 & 115.91 \\
\hline CER_A2 & 94.41 & 120.78 & 63.20 & 36.76 & 39.65 & 73.86 & 133.60 & 115.32 \\
\hline STO_A2 & 93.93 & 125.36 & 64.88 & 34.92 & 38.95 & 72.22 & 132.37 & 115.26 \\
\hline ACM_B1 & 104.09 & 144.79 & 68.41 & 27.76 & 41.38 & 73.33 & 148.61 & 128.13 \\
\hline CER_B1 & 103.50 & 143.44 & 68.47 & 25.99 & 33.10 & 70.47 & 142.63 & 122.10 \\
\hline STO_B1 & 104.33 & 145.96 & 69.33 & 26.89 & 35.10 & 73.94 & 149.63 & 129.11 \\
\hline ACM_B2 & 117.37 & 152.91 & 76.17 & 26.22 & 28.99 & 64.39 & 125.34 & 106.28 \\
\hline CER_B2 & 112.89 & 148.49 & 73.18 & 24.79 & 28.24 & 63.02 & 124.71 & 105.4 \\
\hline STO_B2 & 117.27 & 153.11 & 75.93 & 25.39 & 28.27 & 63.67 & 124.82 & 105.84 \\
\hline ACM_C1 & 113.82 & 158.44 & 75.39 & 27.62 & 34.64 & 75.25 & 152.55 & 130.92 \\
\hline CER_C1 & 108.68 & 150.72 & 71.29 & 24.68 & 30.92 & 69.05 & 141.99 & 120.76 \\
\hline STO_C1 & 107.10 & 152.49 & 70.13 & 22.86 & 31.16 & 71.27 & 150.76 & 129.42 \\
\hline ACM_C2 & 124.44 & 161.89 & 79.58 & 23.61 & 25.57 & 61.44 & 122.38 & 102.62 \\
\hline CER_C2 & 118.60 & 155.88 & 75.80 & 22.37 & 25.07 & 60.26 & 122.09 & 102.13 \\
\hline STO_C2 & 124.85 & 162.53 & 79.70 & 23.13 & 25.10 & 61.02 & 122.02 & 102.3 \\
\hline ACM_D1 & 91.42 & 126.84 & 62.14 & 30.13 & 36.85 & 71.78 & 139.22 & 121.35 \\
\hline CER_D1 & 86.92 & 121.28 & 58.85 & 28.26 & 35.05 & 68.92 & 135.14 & 117.49 \\
\hline STO_D1 & 91.31 & 127.37 & 61.85 & 28.95 & 35.95 & 70.99 & 139.20 & 121.37 \\
\hline ACM_D2 & 85.10 & 117.89 & 57.24 & 26.65 & 32.80 & 65.82 & 129.27 & 112.68 \\
\hline CER_D2 & 84.61 & 117.39 & 56.90 & 26.52 & 32.75 & 65.59 & 129.14 & 112.38 \\
\hline STO_D2 & 84.95 & 117.83 & 57.11 & 26.43 & 32.63 & 65.66 & 129.17 & 112.61 \\
\hline ACM_E1 & 89.52 & 125.94 & 60.38 & 28.08 & 34.94 & 69.80 & 138.42 & 120.59 \\
\hline CER_E1 & 85.22 & 120.48 & 57.24 & 26.42 & 33.28 & 67.09 & 134.37 & 116.75 \\
\hline STO_E1 & 89.58 & 126.57 & 60.23 & 27.13 & 34.25 & 69.21 & 138.54 & 120.73 \\
\hline ACM_E2 & 83.81 & 117.38 & 55.87 & 24.89 & 30.96 & 63.95 & 128.31 & 111.77 \\
\hline CER_E2 & 83.33 & 116.86 & 55.55 & 24.83 & 30.98 & 63.78 & 128.23 & 111.51 \\
\hline STO_E2 & 83.75 & 117.38 & 55.81 & 24.78 & 30.89 & 63.91 & 128.28 & 111.77 \\
\hline MAX & 124.85 & 162.53 & 79.70 & 36.76 & 42.00 & 75.80 & 152.55 & 130.92 \\
\hline MIN & 81.54 & 112.20 & 55.55 & 22.37 & 25.07 & 60.26 & 122.02 & 102.13 \\
\hline
\end{tabular}

Zone 4's climate conditions led to the highest winter energy demand. For these conditions, the optimal solution is the light colour ceramic external layer and inner layer with hollow ceramic brick, lime cement plaster and no insulation (CER_C2), which has the lowest annual demand $\left(22.37 \mathrm{kWh} / \mathrm{m}^{2}\right.$ year). This work confirms that, for specific warm climates, no insulation is best to decrease the annual energy demand [33]. Outer thermal insulation in office buildings has a negative impact in hot Brazilian climates, increasing the energy consumption for cooling, partly due to the lack of internal heat dissipation to the outdoors. In Zones 5, 6, and 8, the lowest energy demand is achieved with 
CER_C2, which is not insulated. In Zone 5, the annual heating demand is quite low, similar to Zone 6, whereas in Zone 7 and Zone 8, no heating demand is required.

The impact of surface colour on energy consumption is not significant, although in colder regions the use of dark colours in non-insulated façades performs best, whereas light colours are better in hotter regions (see Table 6, CER_C2 from Zone 1 to Zone 8).

The optimal solution, regardless of the climatic zone, is CER, varying its performance with the inner configuration, except for Zone 7, where the best result is obtained with STO_C2, although this is quite close to CER_C2.

In the hottest area, Zone 8, no heating is required, and the lowest energy demand is obtained with CER_C2, $\left(102.13 \mathrm{kWh} / \mathrm{m}^{2} \mathrm{~K}\right)$, whereas the highest energy demand is achieved with ACM_C1, reaching $130.92 \mathrm{kWh} / \mathrm{m}^{2} \mathrm{~K}$, both cases without insulation in the inner skin.

Figure 3 shows the temperature across the North façade in Zone 8, where cooling is the only requirement, under the conditions provided by four different constructive solutions, two without insulation ( $a$ and $b$ ) and two with insulation (c and d). In order to compare the results, data on 12 June at 10:00 a.m. where used. Cases $a$ and $b$ are the best and worst solutions, with CER_C2 and ACM_C1, respectively. In the image, the external layer's effect on thermal performance can be seen, reaching a temperature difference of over $10^{\circ} \mathrm{C}$. Cases $\mathrm{c}$ and d show the thermal behaviour with an internal insulated layer combined with two different external layers (CER_A1 and ACM_A1). Comparing temperatures between $\mathrm{c}$ and $\mathrm{d}$, it is possible to see that temperature is lowest with CER_A1, where the outer surface temperature inside the camera is almost $10^{\circ} \mathrm{C}$ lower than with ACM_A1.

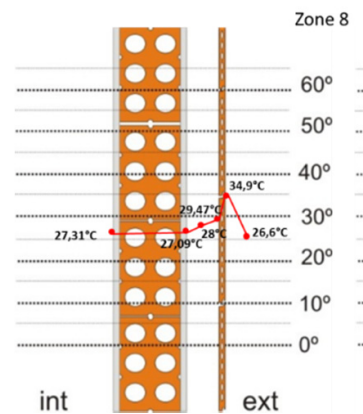

(a)

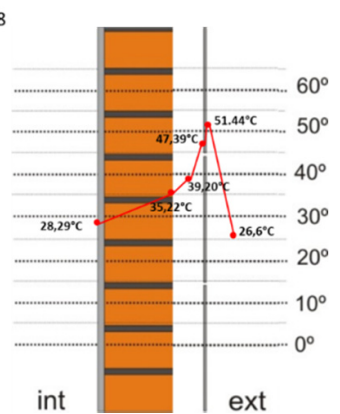

(b)

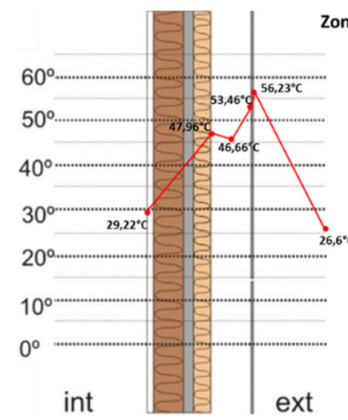

(c)

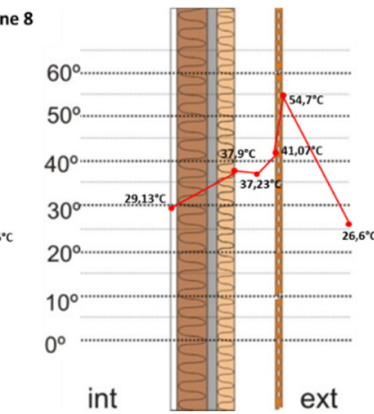

(d)

Figure 3. Temperature fluctuations for Climatic zone 8 on 12 June at 10:00 a.m on the second floor: (a) CER_C2 (best result), (b) ACM_C1 (worst result), (c) ACM_A1 and (d) CER_A1.

Figure 4 shows the temperature inside the ventilated air gap in the north façade both for summer and winter conditions in different climatic zones. The selected façade's constructive solution achieved the lowest energy demand in the simulation, although it is possible to see the effect of the outdoor temperature and the solar radiation during the day on the inside temperature. In Zone 2, it should be noted that the air chamber temperature increases with height, being highest on the fourth floor. In winter, the top floor can reach $35{ }^{\circ} \mathrm{C}$ for CER_A1 in less than four hours, due to the rapid air gap temperature rise. The air cavity's inner temperature increases over $12{ }^{\circ} \mathrm{C}$, whereas in summer, the temperature increment inside the air cavity is lower than $3{ }^{\circ} \mathrm{C}$ during the day. The results obtained in Zone 1 and Zone 3 are like those in Zone 2 because of the climate similarity. In Zone 5, it can be seen that the inner air gap's temperature is quite close to the outdoor temperature in winter, which demonstrates the efficient ventilation system; also, the overheating produced by solar radiation has no influence on the cavity. In summer, the reverse effect is produced and lower temperatures inside the cavity are obtained, because of the efficient ventilation and the lack of solar radiation. Similar thermal behaviour is found in Zone 4, Zone 5, and Zone 6. In Zone 7, the inner cavity's temperature is lower than the external temperature both in winter and summer, and the results in Zone 8 are very similar. 


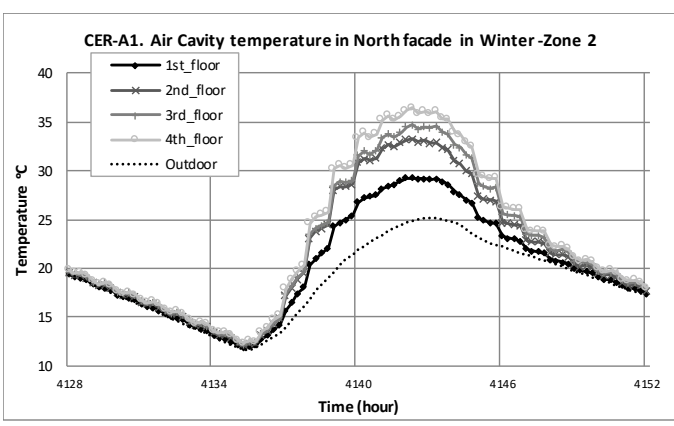

(a)

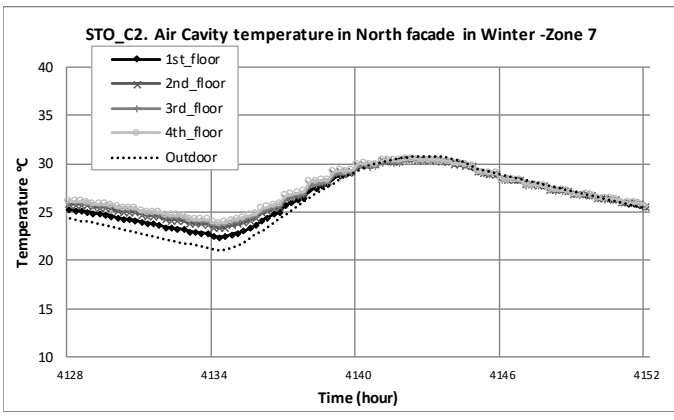

(c)

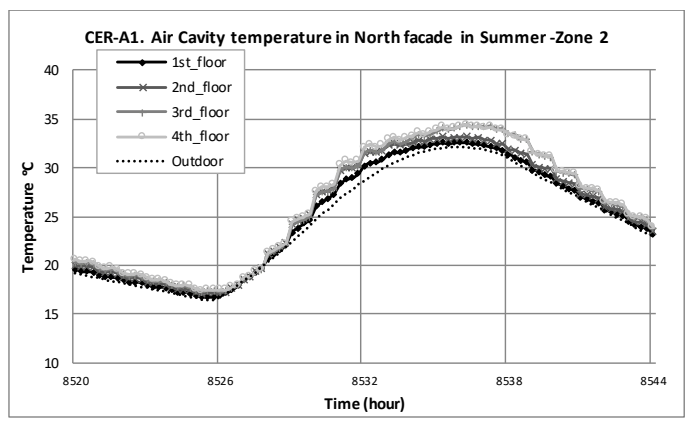

(b)

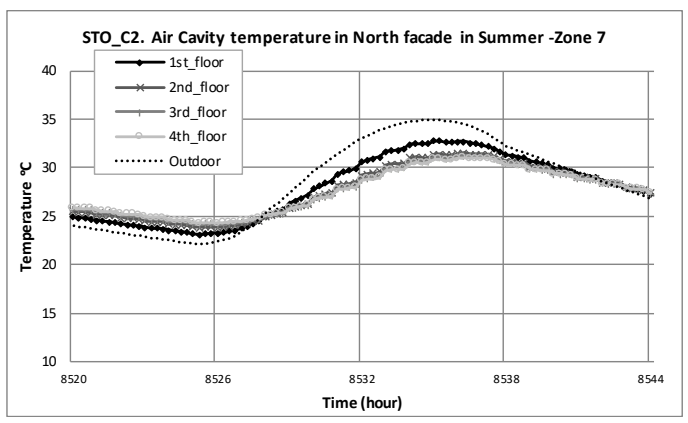

(d)

Figure 4. Temperature inside the ventilated air gap in the North façade from 1st to the 4th floor: (a) CER-A1 in winter (21 June) for Zone 2, (b) CER-A1 in summer (21 December) for Zone 2, (c) STO_C2 in winter for Zone 7 (21 June) and (d) STO_C2 in summer for Zone 7 (21 December).

The effect of solar radiation can be seen in Figure 5, which shows the building's north and south façades with the highest temperature swing produced for ACM_A1 in winter, both for Zone 8 and Zone 1 . As is widely accepted, higher temperature differences lead to higher ventilation rates in this case leading to lower natural ventilation in the South façade. The highest air temperature swing is produced in the North façade, where the maximum temperature swing is $35.64{ }^{\circ} \mathrm{C}$ for Zone 1 and $23.81{ }^{\circ} \mathrm{C}$ for Zone 8 . The lowest temperature swing is produced in the South façade, which in Zone 1 is $1.36^{\circ} \mathrm{C}$ and in Zone 8 is $2.87^{\circ} \mathrm{C}$.

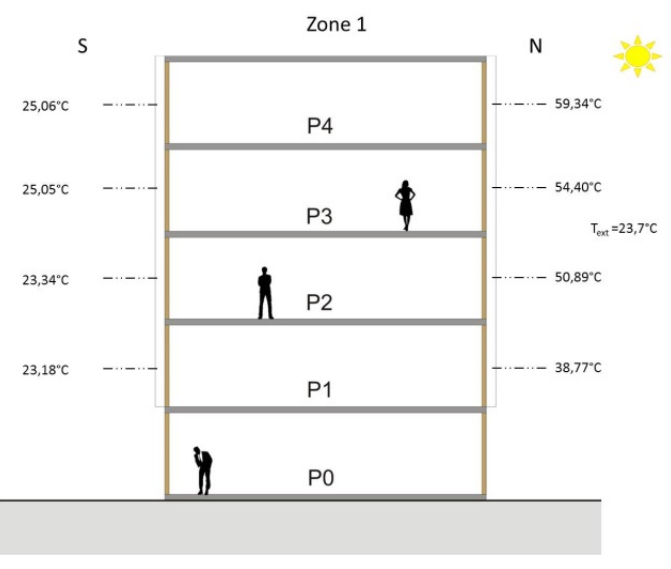

(a)

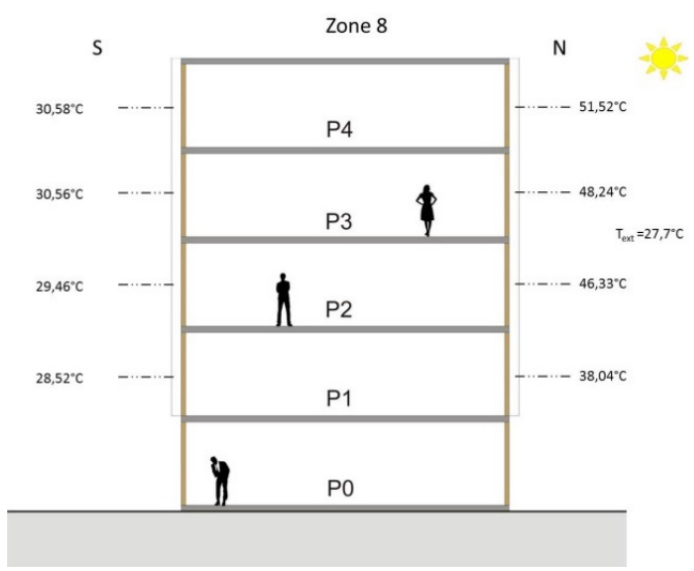

(b)

Figure 5. Winter air cavity temperatures for the south and north façade (Type ACM_A1). (a) On 08 June at 12:30 for Zone 1. (b) On 12 June at 10:45 for Zone 8 


\section{Conclusions}

In the current study, a transient model validated with TRNSYS has been used to analyse the OVF's air gap thermal behaviour under a range of climatic conditions in Brazil for one year. The climatic data used here were taken from a typical meteorological year in eight different Brazilian zones. The simulation results show that the façade's thermal behaviour is strongly related to orientation and climatic conditions. However, in general terms, the external layer with ceramic tiles is the most energy efficient option for almost all the analysed case studies, obtaining the lowest energy demand in the eight zones. Overall, the least energy efficient results are those from stone (STO) and ACM and it is worth noting that lighter colours reduce such differences, being suggested in hot climates, especially for façades without thermal insulation where the colour's effect is higher than in insulated façades. Also, the air cavity's thermal behaviour is strongly influenced by solar gains. In Figure 6, the best OVF for each climatic zone have been summarized.

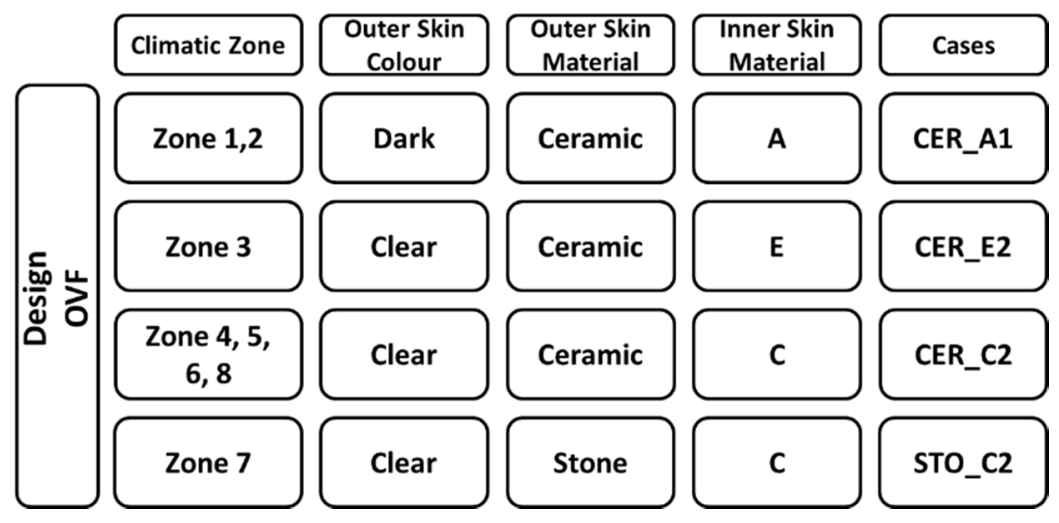

Figure 6. Best solution of opaque ventilated façade (OVF) for each Brazilian climatic zone.

The best OVF design parameters for the external and internal layers of an office building's envelope under different climatic conditions have been determined here. The findings suggest that OVF will be efficient to reduce the cooling demand in hot climates where the temperature inside the air camera is lower than the outdoor temperature. The lowest energy values are those from the façades with the best thermal behaviour in the warmest regions (Zones 4, 5, 6, 7, and 8). This fact is highly relevant for future investments in Brazil, given that it is a developing country and the investment needed for OVF is substantial. Also, in the coldest regions (Zones 1, 2, and 3), the optimum solution for energy demand is higher due to thermal isolation.

For future investigations, it is possible to improve this study by controlling the dimensions of the air openings, the width of the air chamber, and its emissivity.

Author Contributions: Conceptualization, C.G.-A. and C.A.-F.; data curation, C.A.-F.; formal analysis, J.-L.V.; investigation, C.G.-A.; methodology, C.G.-A. and C.A.-F.; resources, C.A.-F.; software, C.G.-A.; supervision, H.C.; validation, C.G.-A., C.A.-F., and J.-L.V.; visualization, C.G.-A. and C.A.-F.; writing-original draft, C.G.-A., C.A.-F. and J.-L.V.; writing-review and editing, C.G.-A., C.A.-F., and J.-L.V. All authors have read and agreed to the published version of the manuscript.

Funding: This research received no external funding.

Conflicts of Interest: The authors declare no conflict of interest.

\section{Appendix A}

The heating and cooling energy demand, calculated for the different façades conditions proposed here, are summarised in Table A1. 
Table A1. Simulation results. Heating and cooling energy demand in $\mathrm{kWh} / \mathrm{m}^{2}$ year.

\begin{tabular}{|c|c|c|c|c|c|c|c|c|c|c|c|c|c|c|c|c|c|c|c|c|c|c|c|c|}
\hline \multirow{2}{*}{ CASES } & \multicolumn{3}{|c|}{ Zone 1} & \multicolumn{3}{|c|}{ Zone 2} & \multicolumn{3}{|c|}{ Zone 3} & \multicolumn{3}{|c|}{ Zone 4} & \multicolumn{3}{|c|}{ Zone 5} & \multicolumn{3}{|c|}{ Zone 6} & \multicolumn{3}{|c|}{ Zone 7} & \multicolumn{3}{|c|}{ Zone 8} \\
\hline & Heat & Cool & otal & eat & Cool & Total & eat & Cool & tal & Heat & Cool & Total & Heat & Cool & Total & eat & Cool & al & at & Cool & otal & at & Cool & Total \\
\hline ACM_A1 & 70.36 & 11.22 & 81.58 & 91.64 & 20.66 & 112.30 & 44.25 & 13.26 & 57.51 & 9.28 & 26.13 & 35.42 & 3.69 & 38.31 & 42.00 & 12.84 & 61.24 & 74.08 & 0.00 & 136.51 & 136.51 & 0.00 & 119.93 & 119.93 \\
\hline CER_A1 & 70.6 & 10.94 & 81.54 & 91.81 & 20.39 & 112.20 & 44.35 & 13.00 & 57.35 & 9.26 & 25.64 & 34.90 & 3.71 & 37.66 & 41.38 & 12.86 & 60.48 & 73.33 & 0.00 & 135.46 & 135.46 & .00 & 118.86 & 118.86 \\
\hline STO_A1 & 81.81 & 10.45 & 92.26 & 104.77 & 20.14 & 124.91 & 51.89 & 12.50 & 64.39 & 12.26 & 24.22 & 36.48 & 5.26 & 6.72 & 41.98 & 15.51 & 60.29 & 75.80 & 00 & 139.26 & 139.26 & 00 & 21.93 & 121.93 \\
\hline ACM_A2 & 71.17 & 10.55 & 82.73 & 92.98 & 19.90 & 112.88 & 45.34 & 12.63 & 57.97 & 9.81 & 24.84 & 34.65 & 5.88 & 34.09 & 39.96 & 13.27 & 59.14 & 72.41 & 0.00 & 133.30 & 133.30 & 0.00 & 115.91 & 115.91 \\
\hline CER_A2 & 84.96 & 9.45 & 94.41 & 101.36 & 19.42 & 120.78 & 50.96 & 12.24 & 63.20 & 12.74 & 24.02 & 36.76 & 6.12 & 33.53 & 39.65 & 15.45 & 58.41 & 73.86 & 0.00 & 133.60 & 133.60 & 0.00 & 115.32 & 115.32 \\
\hline STO_A2 & 84.75 & 9.17 & 93.93 & 106.82 & 18.55 & 125.36 & 53.65 & 11.22 & 64.88 & 13.18 & 21.75 & 34.92 & 5.87 & 33.08 & 38.95 & 16.52 & 55.70 & 72.22 & 0.00 & 132.37 & 132.37 & 0.00 & 115.26 & 115.26 \\
\hline ACM_B1 & 96.53 & 7.56 & 104.09 & 126.18 & 18.61 & 144.79 & 59.18 & 9.23 & 68.41 & 11.25 & 16.51 & 27.76 & 5.24 & 30.30 & 41.38 & 17.04 & 57.06 & 73.33 & 0.00 & 148.61 & 148.61 & 0.00 & 128.13 & 128.13 \\
\hline CER_B1 & 96.74 & 6.77 & 103.50 & 125.97 & 17.47 & 143.44 & 60.05 & 8.42 & 68.47 & 11.02 & 14.98 & 25. & 5. & 27.82 & 33.10 & 16.99 & 53.48 & 70.47 & 0.00 & 142.63 & 42.63 & .00 & 122.10 & 122.10 \\
\hline STO_B1 & 96.93 & 7.40 & 104.33 & 127.30 & 18.66 & 145.96 & 60.27 & 9.06 & 69.33 & 10.89 & 15.99 & 26.89 & 5.04 & 30.06 & 35.10 & 16.97 & 56.96 & 73.94 & 0.00 & 149.63 & 149.63 & 0.00 & 129.11 & 129.11 \\
\hline ACM_B2 & 112.65 & 4.72 & 117.37 & 138.74 & 14.17 & 152.91 & 69.84 & 6.33 & 76.17 & 15.87 & 10.35 & 26.22 & 8.71 & 20.28 & 28.99 & 20.93 & 43.46 & 64.39 & 0.00 & 125.34 & 125.34 & 0.00 & 106.28 & 106.28 \\
\hline CER_B2 & 108.2 & 4.69 & 112.89 & 134.33 & 14.16 & 148.49 & 66.87 & 6.31 & 73.18 & 14.33 & 10.46 & 24.79 & 7.84 & 20.4 & 28.24 & 19.78 & 43.24 & 63.02 & 0.00 & 124.71 & 124.71 & 0.00 & 105.4 & 105.4 \\
\hline STO_B2 & 112.70 & 4.57 & 117.27 & 139.11 & 14 & 153.11 & 69.78 & 6.15 & 75.93 & 15.47 & 9.92 & 25.39 & 8.53 & 19.74 & 28.27 & 20.77 & 42.9 & 63.67 & 0.00 & 124.82 & 124.82 & 0.00 & 105.84 & 105.84 \\
\hline ACM_C1 & 106.77 & 7.05 & 113.82 & 140.26 & 18.18 & 158.44 & 66.83 & 8.56 & 75.39 & 12.64 & 14.98 & 27.62 & 5.81 & 28.83 & 34.64 & 18.86 & 56.39 & 75.25 & 0.00 & 152.55 & 152.55 & .00 & 130.92 & 130.92 \\
\hline CER_C1 & 102.72 & 5.97 & 108.68 & 134.22 & 16.50 & 150.72 & 63.75 & 7.53 & 71.29 & 11.49 & 13.19 & 24.68 & 5.48 & 25.44 & 30.92 & 17.90 & 51.15 & 69.05 & 0.00 & 141.99 & 141.99 & 0.00 & 120.76 & 120.76 \\
\hline STO_C1 & 100.94 & 6.16 & 107.10 & 134.95 & 17.54 & 152.49 & 62.41 & 7.71 & 70.13 & 9.8 & 13.05 & 22.86 & 4.48 & 26.68 & 31.16 & 17.00 & 54.27 & 71.27 & 0.00 & 150.76 & 150.76 & 0.00 & 129.42 & 129.42 \\
\hline ACM_C2 & 120.82 & 3.62 & 124.44 & 149.19 & 12.7 & 161.89 & 74.52 & 5.06 & 79.58 & 15.94 & 7.67 & 23.61 & 9.02 & 16.55 & 25.57 & 21.98 & 39.46 & 61.44 & 0.00 & 122.38 & 122.38 & 0.00 & 102.62 & 102.62 \\
\hline CER_C2 & 114.93 & 3.67 & 118.60 & 143.08 & 12.8 & 155.88 & 70.64 & 5.16 & 75.80 & 14.3 & 8.07 & 22.37 & $\varepsilon$ & 17.07 & 25.07 & 20.55 & 39.71 & 60.26 & 0.00 & 122.09 & 122.09 & 0.00 & 102.13 & 102.13 \\
\hline STO_C2 & 121.33 & 3.52 & 124.85 & 149.96 & 12.57 & 162.53 & 74.76 & 4.94 & 79.70 & 15.74 & 7.39 & 23.13 & 8.93 & 16.17 & 25.10 & 21.94 & 39.08 & 61.02 & 0.00 & 122.02 & 122.02 & 0.00 & 102.3 & 102.3 \\
\hline ACM_D1 & 82.84 & 8.58 & 91.42 & 108.15 & 18.69 & 126.84 & 51.79 & 10.35 & 62.14 & 10.28 & 19.86 & 30.13 & 4.30 & 32.56 & 36.85 & 14.79 & 56.99 & 71.78 & 0.00 & 139.22 & 139.22 & 0.00 & 121.35 & 121.35 \\
\hline CER_D1 & 78.80 & 8.12 & 86.92 & 103.16 & 18.11 & 121.28 & 48.91 & 9.94 & 58.85 & 9.05 & 19.21 & 28.26 & 3.78 & 31.28 & 35.05 & 13.76 & 55.17 & 68.92 & 0.00 & 135.14 & 135.14 & 0.00 & 117.49 & 117.49 \\
\hline STO_D1 & 83.10 & 8.20 & 91.31 & 108.89 & 18.48 & 127.37 & 51.83 & 10.02 & 61.85 & 9.93 & 19.01 & 28.95 & 4.19 & 31.76 & 35.95 & 14.68 & 56.31 & 70.99 & 0.00 & 139.20 & 139.20 & 0.00 & 121.37 & 121.37 \\
\hline ACM_D2 & 77.64 & 7.46 & 85.10 & 100.68 & 17.21 & 117.89 & 47.92 & 9.32 & 57.24 & 8.8 & 17.85 & 26.65 & 3.79 & 29.01 & 32.80 & 13.5 & 52.32 & 65.82 & 0.00 & 129.27 & 129.27 & 0.00 & 112.68 & 112.68 \\
\hline CER_D2 & 77.17 & 7.44 & 84.61 & 100.2 & 17.19 & 117.39 & 47.6 & 9.3 & 56.90 & 8.63 & 17.89 & 26.52 & 3.72 & 29.03 & 32.75 & 13.36 & 52.23 & 65.59 & 0.00 & 129.14 & 129.14 & 0.00 & 112.38 & 112.38 \\
\hline STO_D2 & 77.54 & 7.41 & 84.95 & 100.66 & 17.17 & 117.83 & 47.84 & 9.27 & 57.11 & 8.69 & 17.74 & 26.43 & 3.74 & 28.89 & 32.63 & 13.44 & 52.22 & 65.66 & 0.00 & 129.17 & 129.17 & 0.00 & 112.61 & 112.61 \\
\hline ACM_E1 & 81.67 & 7.85 & 89.52 & 107.94 & 18.00 & 125.94 & 50.78 & 9.60 & 60.38 & 9.34 & 18.74 & 28.08 & 3.71 & 31.23 & 34.94 & 14.05 & 55.75 & 69.80 & 0.00 & 138.42 & 138.42 & 0.00 & 120.59 & 120.59 \\
\hline CER_E1 & 77.79 & 7.43 & 85.22 & 103.03 & 17.44 & 120.48 & 48.01 & 9.23 & 57.24 & 8.24 & 18.18 & 26.42 & 3.25 & 30.03 & 33.28 & 13.08 & 54.00 & 67.09 & 0.00 & 134.37 & 134.37 & 0.00 & 116.75 & 116.75 \\
\hline STO_E1 & 82.04 & 7.54 & 89.58 & 108.74 & 17.83 & 126.57 & 50.90 & 9.33 & 60.23 & 9.09 & 18.04 & 27.13 & 3.64 & 30.61 & 34.25 & 13.99 & 55.23 & 69.21 & 0.00 & 138.54 & 138.54 & 0.00 & 120.73 & 120.73 \\
\hline ACM_E2 & 77.04 & 6.77 & 83.81 & 100.88 & 16.5 & 117.38 & 47.26 & 8.61 & 55.87 & 8.1 & 16.79 & 24.89 & 3.32 & 27.64 & 30.96 & 12.91 & 51.04 & 63.95 & 0.00 & 128.31 & 128.31 & 0.00 & 111.77 & 111.77 \\
\hline CER_E2 & 76.57 & 6.76 & 83.33 & 100.37 & 16.49 & 116.86 & 46.94 & 8.61 & 55.55 & 7.96 & 16.87 & 24.83 & 3.26 & 27.72 & 30.98 & 12.78 & 51 & 63.78 & 0.00 & 128.23 & 128.23 & 0.00 & 111.51 & 111.51 \\
\hline STO_E2 & 77.01 & 6.74 & 83.75 & 100.9 & 16.48 & 117.38 & 47.23 & 8.58 & 55.81 & 8.04 & 16.74 & 24.78 & 3.29 & 27.6 & 30.89 & 12.88 & 51.03 & 63.91 & 0.00 & 128.28 & 128.28 & 0.00 & 111.77 & 111.77 \\
\hline MAX & 121.33 & 9.45 & 124.85 & 149.96 & 20.66 & 162.53 & 74.76 & 13.26 & 79.70 & 15.94 & 26.13 & 36.76 & 9.02 & 38.31 & 42.00 & 21.98 & 61.24 & 75.80 & 0.00 & 152.55 & 152.55 & 0.00 & 130.92 & 130.92 \\
\hline MIN & 71.17 & 3.52 & 81.54 & 91.64 & 12.57 & 112.20 & 44.25 & 4.94 & 55.55 & 7.96 & 7.39 & 22.37 & 3.25 & 16.17 & 25.07 & 12.78 & 39.08 & 60.26 & 0.00 & 122.02 & 122.02 & 0.00 & 102.13 & 102.13 \\
\hline
\end{tabular}




\section{References}

1. Wagner, K. Generation of a tropically adapted energy performance certificate for residential buildings. Sustainability 2014, 6, 8415-8431. [CrossRef]

2. Kumar, G.; Raheja, G. Design Determinants of Building Envelope for Sustainable Built Environment: A Review. Int. J. Built Environ. Sustain. 2016, 3. [CrossRef]

3. Ibañez-Puy, M.; Vidaurre-Arbizu, M.; Sacristán-Fernández, J.A.; Martín-Gómez, C. Opaque Ventilated Façades: Thermal and energy performance review. Renew. Sustain. Energy Rev. 2017, 79, 180-191. [CrossRef]

4. Patania, F.; Gagliano, A.; Nocera, F.; Ferlito, A.; Galesi, A. Thermofluid-dynamic analysis of ventilated facades. Energy Build. 2010, 42, 1148-1155. [CrossRef]

5. Sanjuan, C.; Suárez, M.-J.; Blanco, E.; Del Heras, M.R. Development and experimental validation of a simulation model for open joint ventilated façades. Energy Build. 2011, 43, 3456-3466. [CrossRef]

6. Gagliano, A.; Nocera, F.; Aneli, S. Thermodynamic analysis of ventilated façades under different wind conditions in summer period. Energy Build. 2016, 122, 131-139. [CrossRef]

7. Maciel, A.C.F.; Carvalho, M.T. Operational energy of opaque ventilated façades in Brazil. J. Build. Eng. 2019, 25. [CrossRef]

8. Barth, F.; Grilo, A.C. IX Entorno Nacional de Tecnologia do Ambiente Construido. In Análise Higro-Térmica de Fachadas Ventiladas Nas Condições de Inverno; ENTAC, Ed.; ANTAC: Fowz do Iguacu-Parana, Brazil, 2002; pp. 203-212.

9. BEN. Balanço Energético Nacional. 2019. Available online: http://www.epe.gov.br (accessed on 4 September 2020).

10. MME Empresa de Pesquisa Energética. Plano Nacional de Energia 2030; EPE: Rio de Janeiro, Brazil, 2007; p. 408.

11. Stazi, F.; Tomassoni, F.; Vegliò, A.; Di Perna, C. Experimental evaluation of ventilated walls with an external clay cladding. Renew. Energy 2011, 36, 3373-3385. [CrossRef]

12. Marinosci, C.; Semprini, G.; Morini, G.L. Experimental analysis of the summer thermal performances of a naturally ventilated rainscreen façade building. Energy Build. 2014, 72, 280-287. [CrossRef]

13. Ciampi, M.; Leccese, F.; Tuoni, G. Ventilated facades energy performance in summer cooling of buildings. Sol. Energy 2003, 75, 491-502. [CrossRef]

14. Balocco, C. A simple model to study ventilated facades energy performance. Energy Build. 2002, 34, 469-475. [CrossRef]

15. Suárez, M.J.; Sanjuan, C.; Gutiérrez, A.J.; Pistono, J.; Blanco, E. Energy evaluation of an horizontal open joint ventilated faade. Appl. Therm. Eng. 2012, 37, 302-313. [CrossRef]

16. Giancola, E.; Sanjuan, C.; Blanco, E.; Heras, M.R. Experimental assessment and modelling of the performance of an open joint ventilated façade during actual operating conditions in Mediterranean climate. Energy Build. 2012, 54, 363-375. [CrossRef]

17. Astorqui, J.S.C.; Porras-Amores, C. Ventilated Façade with double chamber and flow control device. Energy Build. 2017, 149, 471-482. [CrossRef]

18. Guillén, I.; Gómez-Lozano, V.; Fran, J.M.; López-Jiménez, P.A. Thermal behavior analysis of different multilayer façade: Numerical model versus experimental prototype. Energy Build. 2014, 79, 184-190. [CrossRef]

19. EnEdi (Grupo de Energética en la Edificación/Área Térmica Laboratorio de Calidad en la Edificación del Gobierno Vasco). Comportamiento Energético de una Fachada Ventilada en la Zona Climatica del Pais Vasco. Available online: https://www.euskadi.eus/contenidos/informacion/estudioareatermica/es_areaterm/ adjuntos/fachadaventilada.pdf (accessed on 29 January 2020).

20. Fantucci, S.; Marinosci, C.; Serra, V.; Carbonaro, C. Thermal Performance Assessment of an Opaque Ventilated Façade in the Summer Period: Calibration of a Simulation Model through in-field Measurements. Energy Procedia 2017, 111, 619-628. [CrossRef]

21. Stazi, F.; Ulpiani, G.; Pergolini, M.; Di Perna, C.; D’Orazio, M. The role of wall layers properties on the thermal performance of ventilated facades: Experimental investigation on narrow-cavity design. Energy Build. 2020, 209, 109622. [CrossRef] 
22. Prada, A.; Baratieri, M.; Gasparella, A. Analysis of the impact of ventilated cavities on the performance of opaque components. In Proceedings of the Building Simulation Applications BSA 2013-1st IBPSA Italy Conference, Bozen-Bolzano, Italy, 30 January-1 February 2013; pp. 353-361.

23. Aparicio-Fernández, C.; Vivancos, J.L.; Ferrer-Gisbert, P.; Royo-Pastor, R. Energy performance of a ventilated façade by simulation with experimental validation. Appl. Therm. Eng. 2014, 66, 563-570. [CrossRef]

24. Pérez-Fargallo, A.; Rubio-Bellido, C.; Gallego-Maya, I. Influence of adaptive comfort models in execution cost improvements for housing thermal environment in Concepción, Chile. Sustainability 2018, 10, 2368. [CrossRef]

25. ABNT. NBR 15222 ASSOCIAÇÃO BRASILEIRA DE NORMAS TÉCNICAS (ABNT). In NBR 15220: Desempenho Térmico de Edificações; ABNT: Rio de Janeiro, Brazil, 2005.

26. Briones-Llorente, R.; Calderón, V.; Gutiérrez-González, S.; Montero, E.; Rodríguez, Á. Testing of the integrated energy behavior of sustainable improved mortar panels with recycled additives by means of energy simulation. Sustainability 2019, 11, 3117. [CrossRef]

27. Alvares, C.A.; Stape, J.L.; Sentelhas, P.C.; De Moraes Gonçalves, J.L.; Sparovek, G. Köppen's climate classification map for Brazil. Meteorol. Z. 2013, 22, 711-728. [CrossRef]

28. Meteotest Meteonorm Handbook, Parts I, II and III; Meteotest: Bern, Switzerland, 2003.

29. ISO. ISO 1991-1-4: 2018 Eurocode 1: Actions on structures. Part 1-4: General actions. Wind actions. International Standard Organization; International Organization for Standardization: Geneva, Switzerland, 2018; pp. 1-13.

30. ISO. ISO 6946:2017 Building Components and Building Elements-Thermal Resistance and Thermal TransmittanceCalculation Method 2017; International Organization for Standardization: Geneva, Switzerland, 2017; pp. 1-36.

31. Lamberts, R.; Candido, C.; De Dear, R.; De Vecchi, R. Towards a Brazilian Standard on Thermal Comfort; Florianópolis LabEEE: Florianópolis, Brazil, 2013; p. 123.

32. ISO. ISO 10456:1997 ISO Standard, Building Materials and Products—Hygrothermal Properties e Tabulated Design Values and Procedures for Determining Declared and Design Thermal Values; International Organization for Standardization: Geneva, Switzerland, 2017.

33. Westphal, F.S.; Yamakawa, M.A.; Tavares de Castro, L. Thermal insulation of building envelope toward zero energy design in hot-humid climate. In Proceedings of the International Building Performance Simulation Association, Sydney, Australia, 14-16 November 2011; pp. 2378-2384. 